\title{
As contribuições de uma sequência didática voltada para 0 estudo das relações de ângulos na circunferência \\ The contributions of a didactic sequence for the study of angle relations in the circumference
}

\author{
JOABY DE OLIVEIRA SILVA ${ }^{1}$ \\ LÍGIA SOUSA BASTOS ${ }^{2}$ \\ GILSON BISPO DE JESUS ${ }^{3}$
}

\begin{abstract}
RESUMO
A ideia desse trabalho nasce em uma disciplina de mestrado, em que tivemos a oportunidade de refletir sobre alguns conceitos geométricos e seu ensino. Dentre as atividades dessa disciplina estava a construção de uma sequência didática, a qual é analisada neste texto. Assim, objetivamos identificar as contribuições de uma sequência didática, com o uso do software GeoGebra, para o aprendizado das relações de ângulos na circunferência. A sequência foi elaborada com base na Teoria das Situações Didáticas, seguindo as quatro etapas da Engenharia Didática: análises preliminares; concepção e análise a priori; experimentação; $e$ análise a posteriori e validação. Essa sequência foi aplicada com alunos da licenciatura em matemática de uma universidade pública. Percebemos que a sequência contribuiu para descobertas de propriedades relativas à ângulos na circunferência. Também notamos que o GeoGebra foi utilizado como fonte de dados confiáveis para conjectura e validação de propriedades geométricas. Entretanto, encontramos algumas limitações, como o número reduzido de estudantes que participaram da aplicação e a notória afinidade deles com a forma de argumentar em matemática.
\end{abstract}

Palavras-chave: Ângulos na Circunferência. Teoria das Situações Didáticas. GeoGebra.

\begin{abstract}
The idea of this work arises in a master's degree, in which we had the opportunity to reflect on some geometric concepts and their teaching. Among the activities of this discipline was the construction of a didactic sequence, which analyzed in this text. Thus, we aimed to identify the contributions of a didactic sequence, with the use of GeoGebra software, to learn the relations of angles in the circumference. The sequence elaborated based on the Theory of Didactic Situations organized according to the four stages of Didactic Engineering: preliminary analyzes; a priori design and analysis; experimentation; and a posteriori analysis and validation. This
\end{abstract}

\footnotetext{
${ }^{1}$ joabyjos@hotmail.com

2 Secretaria de Educação do Estado da Bahia - ligiasousabastos@gmail.com

${ }^{3}$ Universidade Federal do Recôncavo da Bahia - gilbjs@bol.com.br
} 
sequence applied to undergraduate students in math from a public university. We noticed that the sequence contributed to discoveries of properties related to the angles in the circumference. We also noticed that GeoGebra used as a reliable data source for conjecture and validation of geometric properties. However, we found some limitations such as the reduced number of students who took part in the application and their marked affinity with mathematical reasoning.

Keywords: Angles in Circumference. Theory of Didactical Situations. GeoGebra.

\section{Introdução}

Este trabalho é fruto de pesquisas realizadas no âmbito da disciplina Tópicos de Geometria sob a Perspectiva da Educação Matemática do Mestrado em Educação Matemática da UESC. Nesta disciplina, muitos temas e problemas inerentes ao ensino e à aprendizagem da Geometria foram estudados, dentre eles, está a recorrente prática de iniciar a abordagem de novos saberes geométricos por meio da apresentação de definições. O fato é que não só as definições são ensinadas dessa forma, como também as propriedades dos objetos matemáticos são expostas como elementos prontos e acabados.

$\mathrm{Na}$ contramão dessas práticas de ensino, vemos vários trabalhos fundamentados em ideias sociointeracionistas (NOGUEIRA FARIAS; FARIAS, 2007; LOPES, 2013; MELO; DRAGHI; SALDIVIAN, 2015), as quais pregam mudanças nas interações entre os três elementos fundamentais das relações didáticas, sendo eles o professor, o aluno e o saber. Nessa perspectiva, que busca romper com paradigmas estabelecidos por um ensino tradicional de matemática, ensino em que se tem, por exemplo, o anúncio de uma propriedade seguida de exemplos e exercícios de fixação, é dado ao aluno o papel de sujeito ativo na construção do seu conhecimento. No entanto, o professor não se torna mais passivo devido à maior participação do aluno, ele apenas passa a agir mais por meio de suas escolhas metodológicas, na seleção de ferramentas de interação do aluno com o saber e no acompanhamento do processo de aprendizagem.

No tocante às ferramentas de interação do aluno com objetos do saber geométrico, Jones e Tezekaki (2016) apresentam um levantamento que mostra o aumento constante de pesquisas com ênfase no uso de tecnologias e de como elas têm impactado no ensino e na aprendizagem de Geometria. Esse movimento a favor do uso de tecnologias tem influenciado diversos documentos oficiais, tanto internacionais quanto nacionais. Os Parâmetros Curriculares Nacionais de Matemática - PCN - (BRASIL, 1998), por exemplo, a mais de vinte anos atrás já defendia que o uso dos recursos tecnológicos permite repensar o processo de ensino e aprendizagem de Geometria, pois possibilita o "desenvolvimento da autonomia [do 
aluno] pelo uso de softwares que possibilitem pensar, refletir e criar soluções" (BRASIL, 1998, p. 44). A Base Nacional Comum Curricular (BNCC) mantem a indicação do uso de tecnologias digitais no ensino da Matemática ao explicitar, na quinta competência específica, o emprego dessas ferramentas com a finalidade de modelar e resolver problemas. Além disso, o uso de softwares aparece em diversas habilidades a serem desenvolvidas pelos alunos, como a EF06MA20, EF08MA04 e muitas outras.

Ainda sobre o tema do potencial das tecnologias, a BNCC afirma que recursos didáticos, dentre eles, os softwares de geometria dinâmica, "têm um papel essencial para a compreensão e utilização das noções matemáticas" (BRASIL, 2017, p. 232) desde que integrados a situações que levem à reflexão e à sistematização. Isso se dá porque esses programas são construídos fundamentados em ideias matemáticas e, por assim serem, permitem que os usuários manipulem diferentes representações de um mesmo objeto matemático, com maior agilidade e precisão. Além disso, muitos softwares desenvolvidos para o ensino de matemática permitem que o usuário construa novas ferramentas a partir das que o compõe. Dentre esses programas, temos os softwares de geometria dinâmica, os quais "podem favorecer a construção de conceitos; a emergência a compreensão e a dedução de propriedades das figuras geométricas" (BAIRRAL; BARREIRA, 2017, p. 53).

O GeoGebra é um exemplo deste tipo de software de geometria dinâmica. O nome dele deriva da união das palavras "Geometria" e "Álgebra", por permitir a representação de determinados objetos matemáticos nos registros gráfico e algébrico, além disso, a representação numérica também pode ser obtida (FERRAGINA et. al., 2012; BAIRRAL; BARREIRA, 2017, p. 53). Desse modo, ao construirmos uma circunferência na Janela de Visualização do GeoGebra, a equação referente a ela aparecerá na Janela de Álgebra, a qual também exibe a medida do comprimento da circunferência e as coordenadas do centro no registro numérico.

Diante das potencialidades apresentadas pelo GeoGebra, decidimos elaborar uma sequência didática ${ }^{4}$ composta de quatro situações voltadas para o estudo de ângulos na circunferência. Mais precisamente, a primeira situação destina-se ao estudo dos Ângulos Inscritos numa Circunferência e a segunda é um caso particular da primeira, pois trata-se de um Ângulo Inscrito numa Semicircunferência. Enquanto que a terceira e quarta situações giram em torno da relação entre a medida de arcos e a medida de um Ângulo Excêntrico Interno e Ângulo Excêntrico Externo, respectivamente.

\footnotetext{
${ }^{4}$ Baseados em Artigue (1988) e Henriques (2011) entendemos que uma Sequência Didática é um conjunto de situações (atividades, tarefas ou problemas), que são elaboradas com um objetivo bem definido envolvendo um determinado objeto do saber. Essas situações, após passarem por estudos matemático e didático, são aplicadas em sessões.
} 
Assim, a pesquisa apresentada neste texto se insere no contexto do ensino de Geometria por meio do uso de tecnologias, ao apresentar uma sequência didática elaborada com o uso do GeoGebra para trabalhar a relação entre arcos e ângulos na circunferência. Neste trabalho, o objetivo foi identificar as contribuições de uma sequência didática elaborada, com o uso do recurso do GeoGebra para o aprendizado das relações de ângulos na circunferência.

Neste sentido, apresentaremos na seção que segue as principais ideias da Teoria das Situações Didáticas, que nos auxiliaram na elaboração, implementação e análise da sequência didática. Em seguida, traremos a metodologia utilizada, os pressupostos da Engenharia Didática, a qual deu formato a esta pesquisa. $\mathrm{Na}$ sequência, apresentaremos uma análise a priori de cada situação da sequência didática, seguida da sua análise a posteriori após implementação da sequência didática. E, na última seção, escrevemos nossas considerações finais sobre todo o processo de pesquisa que deu origem a este trabalho.

\section{Teoria das Situações Didáticas}

A Teoria das Situações Didáticas (TSD), proposta por Guy Brousseau, tem como um de seus pressupostos que todo saber matemático está associado a uma situação fundamental, cuja solução é dada de forma ótima pelo emprego deste saber (CHEVALLARD; BOSCH; GASCÓN, 2001). Vista deste prisma, a TSD considera a matemática como fruto da ação humana sobre a realidade, como uma construção cultural. Mesmo não discordando da existência de outras matemáticas, e sendo passível de ser aplicada aos processos de ensino e aprendizagem desses saberes, a TSD vem sendo utilizada no processo de comunicação do conjunto de saberes que compõe a chamada matemática escolar.

Nesse processo de comunicação estão envolvidos três elementos fundamentais: o professor; o aluno; e o objeto do saber. Assim, a TSD conta com um conjunto de conceitos que podem ser usados para modelar e analisar as relações estabelecidas entre essa tríade didática num determinado meio (BROUSSEAU, 2007). Esse conceito de meio é um dos mais importantes dessa teoria, pois ele é visto como um dispositivo antagônico ao aluno, no sentido em que reage às ações dele. Essas reações são importantes porque dão ao aprendiz as primeiras características do saber que o professor busca ensinar. Outra característica do meio é que ele é organizado pelo professor, o qual seleciona uma série de situações matemáticas que estão associadas diretamente ao saber específico que se quer ensinar. 
As situações matemáticas referidas anteriormente são de tal forma que, mesmo sem uma indicação explícita do professor, o aluno, ao tentar resolvê-las, modifica sua estratégia no jogo com o saber, ou seja, suas interações individuais com o objeto deixam, paulatinamente, de ser arbitrárias e passam a ter seus resultados antevistos. Cada uma dessas situações matemáticas, que provocam essa interação do aluno com o saber, é denominada por situação adidática (BROUSSEAU, 2007).

As situações adidáticas podem ser de três tipos: de ação; de formulação; e de validação. Elas iniciam após o processo de devolução, no qual o professor propõe um problema de tal forma que o aluno aceita a responsabilidade de encontrar a solução. Ao aceitar este encargo, o aluno passa a manipular os elementos disponíveis no meio de forma exploratória e o meio lhe retorna informações que são processadas pelo aluno e usadas para a elaboração do modelo implícito. Esse modelo é uma solução ótima e possível para o problema proposto, e a primeira relação do aluno com o saber, embora, em geral, ainda não possa ser comunicado a outras pessoas. Todo esse processo de exploração do meio da elaboração de uma possível forma de resolver o problema constitui a fase da situação adidática de ação.

No entanto, como o aluno aceitou a responsabilidade de resolver o problema, ele se vê na obrigação de apresentar uma solução para seus pares (professor e colegas). É essa necessidade de comunicar ao outro como se pode chegar à resposta do problema que faz o aluno entrar na fase da situação adidática de formulação. Nela, busca-se transformar o modelo implícito em explícito, então o aluno utiliza os diferentes registros (a língua materna, gráfico, algébrico ou numérico) que ele tem a sua disposição e que podem ser interpretados pelos seus pares.

Contudo, não basta obter um modelo explícito, ele tem que vir acompanhado de argumentos que confirmem sua efetividade enquanto solução para o problema proposto. Nesse caso, o aluno entra na fase da situação adidática de validação. A esse respeito, Chevallard, Bosch e Gascón (2001, p. 222) escrevem:

\footnotetext{
A validação empírica obtida nas fases precedentes é insuficiente. $\mathrm{Na}$ dialética da validação, o aluno deve demonstrar por que o modelo que criou é válido. Mas, para que o aluno construa uma demonstração e essa tenha sentido para ele, é necessário que a construa em uma situação, chamada de validação, na qual deve convencer alguma outra pessoa.
}

Assim, vemos que essa terceira fase gira em torno da promoção de significado para as ações realizadas nas situações adidáticas de ação e formulação. Contudo, apesar dos autores apresentarem a palavra demonstração, segundo Balacheff (1982) o que os alunos fazem verdadeiramente são provas. Segundo este autor, existe uma diferenciação entre o que se constitui como explicação, prova e demonstração. Para 
Balacheff (1982), uma explicação é uma forma de comunicar à um interlocutor a veracidade de um enunciado matemático. Enquanto isso, a prova se constitui como um tipo de explicação que é reconhecida por um conjunto específico de pessoas. E, no caso da demonstração, ela é o único tipo de prova que é aceita pela comunidade matemática, além disso, respeita regras lógicas específicas e trabalha sobre os objetos matemáticos de forma abstrata. Nesse caso, o tipo de explicação apresentada pelos alunos no processo de validação são, na verdade, provas e não demonstrações.

Com isso, percebemos que o saber está ligado a uma série de ações realizadas pelo aluno, mas este, enquanto membro de uma instituição, ou seja, pertencente a um grupo cultural, necessita saber qual dessas ações são reconhecidas como saber pela cultura na qual está inserido. É nesse instante que o professor retoma o protagonismo ao evidenciar, por meio de uma situação didática de institucionalização, qual das atividades realizadas pelos alunos têm reconhecimento científico, ou qual pode ser considerada uma prática oficial daquela instituição de ensino.

Podemos notar que há, essencialmente, dois tipos de situações, as didáticas e as adidáticas. Na primeira, o professor tem grande influência e controle, já no segundo tipo, é o aluno quem protagoniza todas as ações. Isso está relacionado com o chamado Contrato Didático, o qual não é um contrato físico como os comumente encontrados nos meios jurídicos. Esse conceito diz respeito aos compromissos assumidos pelo professor e pelo aluno diante do processo de ensino e aprendizagem de um novo saber. Ele é considerado paradoxal, pois, segundo Brousseau (2007), se o professor ensina, apresenta as características do saber para o aluno, ele não estabelece uma relação pessoal com o saber, não aprende. Em contrapartida, se o aluno aprende, ou seja, explora e descobre por si só as características principais do objeto do conhecimento, o professor não ensinou de fato. Neste sentido, o aprendizado ocorre, de fato, num constante transitar entre ensinar e aprender.

Essa constante alternância se dá, essencialmente, por meio de devoluções. Ou seja, o professor prepara as situações e efetua a primeira devolução - convence o aluno a aceitar a responsabilidade de resolver a situação. Uma vez que tenha aceitado, o aluno poderá encontrar dificuldade para realizar sua tarefa, levando-o a fazer perguntas ao professor que, por sua vez, as reformula e executa outra devolução para o aluno.

As ideias da Teoria das Situações Didáticas apresentadas nos auxiliaram claramente no trabalho em sala de aula. No entanto, nosso objetivo abrange um trabalho pré-sala de aula, que consiste na elaboração das situações segundo os conceitos da TSD, abrangendo as duas primeiras etapas do aporte metodológico adotado, que foi a Engenharia Didática nos termos descritos por Artigue (1988). Além disso, um trabalho pós-sala de aula, que é a análise sobre o grau de efetividade 
das situações propostas para a aprendizagem dos alunos, nos quais a TSD aparece, juntamente com os aspectos indicados pela Engenharia Didática. As principais características desse aporte metodológico serão expostas na seção seguinte.

\section{Aspectos metodológicos}

A pesquisa que apresentamos segue os moldes de uma Engenharia Didática, a qual, segundo Artigue (1988), se apoia nos conhecimentos e na vigilância do tipo científico, no entanto, lida com outros objetos e fatores externos. Neste contexto, Almouloud (2007, p. 171) afirma que a Engenharia Didática, enquanto metodologia de pesquisa, é essencialmente experimental e perpassa pela "construção, observação e análise de sessões de ensino".

Essa metodologia é apresentada por Pais (2002) como sendo composta por quatro etapas: análise preliminar; concepção e análise a priori; aplicação da sequência didática; e análise a posteriori e validação. No caso dessa pesquisa, a primeira etapa abrange todas as discussões ocorridas na disciplina mencionada na introdução. Essas discussões giraram em torno dos Parâmetros Curriculares Nacionais de Matemática, da Base Nacional Comum Curricular, do National Council of Teachers of Mathematics (NCTM), do uso de metodologias para ensino da Geometria e do estudo do conteúdo matemático em livros usados na Educação Básica e Superior.

Os elementos dessa primeira fase foram considerados na concepção e análise a priori da sequência didática. Uma vez que os objetos matemáticos abordados são Medidas de Ângulos e Medidas de Arcos, percebemos que trabalhar com desenhos estanques poderia gerar dúvidas ou dificultar a identificação de algumas propriedades desses objetos. Assim, decidimos que, utilizar as Tecnologias da Informação e Comunicação enquanto recurso para o ensino da matemática, seria uma opção que poderia trazer contribuições para esta pesquisa. Diante disso, optamos por utilizar o GeoGebra como recurso na preparação das situações que compõem a Sequência Didática (SD).

Uma vez definido como abordaríamos os conteúdos, prosseguimos com a construção de quatro situações, a primeira sobre Ângulo Inscritos na Circunferência, a segunda sobre Ângulos Inscritos na Semicircunferência, a terceira voltada aos Ângulos Excêntricos Internos e a quarta para Ângulos Excêntricos Externos. Essas situações foram apresentadas, discutidas e modificadas, em conjunto, com todos os participantes (professores e alunos) da disciplina. Na sequência, realizamos a análise a priori, na qual explicitamos os objetos geométricos a serem mobilizados em cada 
item de cada situação e como ocorreria cada uma das quatro fases descritas pela TSD, e mais, apresentamos o objetivo de cada situação e discussões didáticas. Além disso, tentamos antever possíveis entraves decorrentes do uso do software GeoGebra por parte dos alunos, suas possíveis respostas e erros e como trataríamos cada um desses durante o processo da aplicação da SD.

Com esta primeira análise feita, iniciamos a terceira etapa da Engenharia Didática. A aplicação da sequência didática aconteceu em uma única sessão, com a participação de cinco estudantes do curso de licenciatura em matemática de uma universidade pública, os quais foram divididos em dois grupos, um com três alunos e outro com dois. Estes participantes já haviam cursado uma disciplina na qual aprenderam a utilizar o GeoGebra, logo, as características do software não foram uma fonte geradora de dificuldades. Entregamos aos grupos uma situação por vez, eles respondiam, nós institucionalizávamos os saberes abordados e, em seguida, entregávamos a situação seguinte.

Este processo de implementação da SD foi registrado em gravações de áudio, as quais foram transcritas e analisadas. Outra fonte de dados para esta pesquisa foram os arquivos do GeoGebra, contendo as construções realizadas por cada grupo, referentes a cada situação. Assim, na análise a posteriori comparamos as resoluções apresentadas por cada grupo, por meio das transcrições entendemos o percurso dos estudantes para chegar até essas resoluções e como eles se envolveram no processo de institucionalização. Neste artigo, apresentamos principalmente os resultados do processo de validação, ou seja, da confrontação da análise $a$ priori com a análise $a$ posteriori.

\section{Análises}

Nas subseções seguintes, apresentamos, para cada atividade, uma análise realizada logo após a elaboração e outra análise baseada nos dados oriundos da aplicação de cada uma e, por fim, apresentamos a validação dos resultados da sequência.

\subsection{Análise a priori e a posteriori}

A sequência didática foi construída para ser desenvolvida utilizando o software GeoGebra. Dessa forma, o professor que aplica esta sequência supõe que seus alunos já passaram por um processo de "familiarização" com o software, ou seja, tenham desenvolvido a capacidade de associação de seus conhecimentos e experiências com as características e potencialidades do GeoGebra. Caso isso não tenha acontecido, o processo de aprendizagem estaria comprometido, pois o aluno 
não teria como interagir com o meio preparado. Assim, teríamos um obstáculo didático (BROUSSEAU, 2007), pois a aprendizagem seria inviabilizada por conta de uma escolha do professor.

No entanto, o professor pode fazer intervenções durante os primeiros passos de cada situação, pois estas são ações de construção do objeto geométrico. A construção mobiliza conhecimentos geométricos prévios - por exemplo, ângulos, circunferência, semirreta, segmento de reta etc. - e conhecimentos relativos à utilização do software. Caso o aluno não se lembre de algum desses objetos geométricos, o professor pode fazer questionamentos. Por exemplo, se o aluno não lembrar o que é uma semirreta, então o professor pergunta se ele lembra o que é uma reta, e pergunta o que é uma parte dessa reta "dividida ${ }^{5}$ a partir de um ponto". No tocante à forma de manipular o GeoGebra, o professor pode solicitar que o aluno abra uma determinada caixa de ferramenta e observe os nomes das ferramentas contidas nela, e escolha a que ele acha que serviria para realizar a ação.

A seguir, estão quatro subseções (3.1.1, 3.1.2, 3.1 .3 e 3.1.4) nas quais são apresentadas as análises a priori e a posteriori de cada situação da SD. Após estas, há outra subseção dedicada à fase de validação, na qual trazemos uma reflexão e confrontação entre as duas análises realizadas sobre a SD. Optamos pela apresentação das duas análises de cada situação, uma seguida da outra, com o intuito de facilitar a compreensão daquilo que esperávamos ao elaborar a situação e o que realmente ocorreu durante a implementação.

\subsubsection{Situação 1: Ângulo Central e Ângulo Inscrito numa Circunferência:}

Esta situação tem por objetivo que o aluno compreenda que a medida do ângulo inscrito está relacionada com a medida do ângulo central correspondente, sendo que a primeira é a metade da segunda. Logo no início, a situação traz a seguinte informação: "Todo arco está associado a um ângulo central e a medida do arco em graus é igual a medida do ângulo central". Esta informação deve ser interpretada e usada pelos alunos, uma vez que ela é a base da relação entre ângulos e os arcos da

\footnotetext{
5 Matematicamente não é correto utilizar o termo "dividida", mas sim "particionada", pois o primeiro faz referência à operação de divisão, o que não é possível realizar com uma reta, porque esta é um conjunto infinito de pontos. Enquanto que o segundo termo, faz referência a particionar um conjunto, sendo que cada partição é também um conjunto e a união de todas as partições resulta no conjunto inicial. No entanto, sugerimos o uso do termo "dividida" por não haver garantias que os estudantes conheçam o conceito de partição, o que não traz impedimento para alcançar o objetivo da situação matemática proposta.
} 
circunferência. Após isso, encontramos o primeiro passo da situação 1, que é apresentada a seguir.

1. Construa uma circunferência de centro A passando por três pontos $C, D$ e E;

Para cumprir esta ação no GeoGebra o aluno pode seguir três caminhos, os quais se diferem essencialmente pela ferramenta do GeoGebra que ele irá utilizar: pode usar a ferramenta "Círculo dados Centro e um de seus Pontos" e, posteriormente, criar os pontos $\mathrm{C}$ e $\mathrm{D}$ sobre a circunferência criada; análogo ao primeiro caminho, pode-se utilizar a ferramenta "Círculo: centro \& raio" para criar uma circunferência; ou usar a ferramenta "Círculo definido por três pontos" para criar a circunferência e, em seguida, "Ponto médio ou centro" para determinar o centro da circunferência. Essa diversidade de formas não geraria problema, uma vez que todas as ferramentas apresentam, mais ou menos, o mesmo grau de dificuldade para seu uso, e os resultados são equivalentes. Uma vez construída essa circunferência da primeira tarefa, é solicitado aos estudantes que:

2. Trace duas semirretas $\overrightarrow{E C}$ e $\overrightarrow{E D}$ e trace os segmentos $\overline{A C}$ e $\overline{A D}$;

3. Meça os ângulos $C \hat{E} D$ e $C \hat{A} D$.

Esses itens trabalham com a noção de ângulo enquanto inclinação (ou abertura) relativa a duas semirretas (segmentos de retas) relativas a um ponto comum, o qual é denominado vértice do ângulo. Nesta construção, o ângulo CÂD é dito ângulo central relativo à circunferência, pois seu vértice está no centro da circunferência. Já o ângulo CÊD é dito ângulo inscrito relativo à circunferência, pois seu vértice está sobre a circunferência e seus lados são secantes a ela.

Até este ponto, o aluno apenas segue instruções dadas por escrito pelo professor para executar a construção, apresentada na Figura 1.
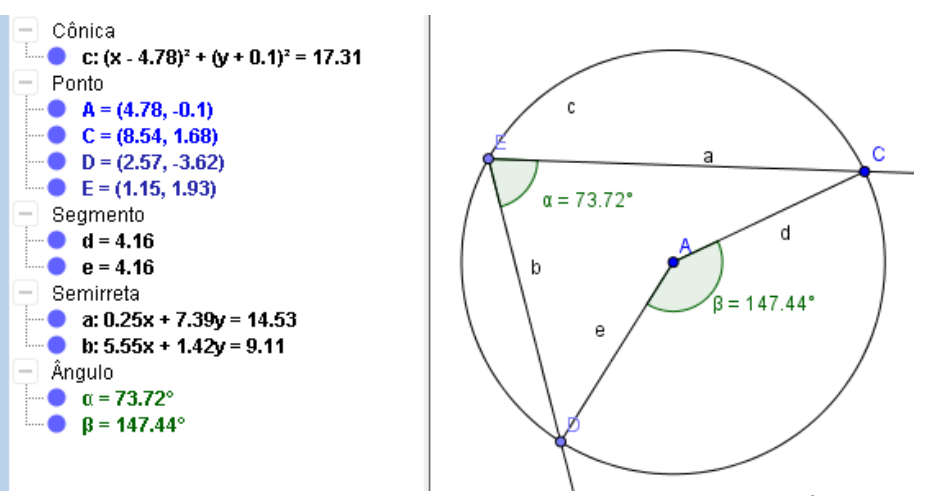

FIGURA 1: Construção realizada por um dos grupos participantes ${ }^{6}$ da pesquisa relativa a situação 1 .

\footnotetext{
${ }^{6} \mathrm{Na}$ apresentação da análise a priori das Situações 1 e 2, optamos por usar a imagem da construção realizada pelos alunos por dois motivos: primeiro, entendemos que, nesse momento do texto, a imagem já se fazia necessária para facilitar a compreensão do leitor; segundo, a
} 
FONTE: Dados coletados na fase de experimentação da sequência didática.

No entanto, aqui surge uma variável didática ${ }^{7}$, que é a escolha dos ângulos a serem observados, e os valores assumidos pela variável são CÊD e CÂD. Neste momento, a atenção dos alunos será direcionada para as observações sobre os aspectos desses ângulos e não de outros, pois o ângulo CÊD é o ângulo inscrito relativo ao mesmo arco associado ao ângulo central CÂD.

A partir do momento em que os estudantes obtenham uma construção semelhante à da Figura 1, propomos a seguinte questão a eles:

a) Existe alguma relação entre as medidas desses ângulos?

Assim, o subitem a) é posto para que os alunos explorem melhor a situação de ação e identifiquem os elementos sobre o conhecimento necessários para uma futura situação de formulação. Essa questão é um instrumento construído pelo professor para estimular, de forma indireta, as ações dos alunos durante as situações adidáticas de ação e de formulação. Uma vez feita a construção, o aluno se questionará sobre a intensão didática por detrás da construção, procurará saber o que o professor quer lhe ensinar (ou o que quer que ele aprenda). Neste momento em que os alunos estão imersos em informações obtidas pela construção e desejando saber o que o professor que lhes ensinar, os subitens b) e c) da sequência dão para eles mais pistas, como podemos ler:

b) Investigue!

c) O que você pode conjecturar?

Esses dois subitens, b) e c), estão relacionados com a situação adidática de formulação, pois terão que elaborar uma explicação em uma linguagem compreensível para outras pessoas e para si, chamada modelo explícito da relação entre os ângulos. O modelo explícito desejável (solução ótima) será que a medida do ângulo inscrito é a metade da medida do ângulo central.

\section{Confirme a sua conjectura com ações e ferramentas do GeoGebra;}

Esta etapa consiste num terceiro momento construído para que o aluno se envolva numa situação adidática de validação, para isso, ele poderá: inicialmente, efetuar a divisão entre as medidas do ângulo central pelo inscrito, obtendo 2 como resultado, ou a medida do ângulo inscrito pelo central, obtendo $1 / 2$, percebendo assim a relação desejada; movimentar um dos pontos sobre a circunferência de tal forma

construção dos alunos foi muito semelhante à que fizemos durante a elaboração da sequência. Então, se colocássemos nossas construções na análise a priori e a dos alunos na parte da análise a posteriori, teríamos uma repetição incompatível com o espaço limitado de um artigo. Assim, essa opção não implica que a análise $a$ priori não foi realizada antes da aplicação da sequência didática.

7 São elementos da situação adidática que, ao assumirem determinados valores, promovem mudanças na solução do problema proposto. Elas são ditas didáticas, pois estão ao alcance do professor para serem fixadas ou modificadas de acordo com o objetivo didático (BROUSSEAU, 2007; CHEVALLARD; BOSCH; GASCÓN, 2001). 
que as medidas dos ângulos sejam números inteiros, a partir disso ele notará que a medida do ângulo inscrito é a metade da medida do ângulo central; multiplicar a medida do ângulo inscrito por 2 e confirmar que o resultado da multiplicação é igual a medida do ângulo central.

Caso o aluno não consiga confirmar, o professor poderá atuar fazendo questionamentos, tais como: E se você dividisse as medidas dos ângulos CÊD pelo CÂD usando o campo de Entrada do GeoGebra? Que resultado você obtém?; Movimente os três pontos criados sobre a circunferência, o que você pode observar?; Por meio da observação das medidas dos ângulos e do quociente deles, como podemos escrever a relação entre as medidas desses dois ângulos?

\section{Enuncie a sua conjectura (matematicamente).}

Neste ponto, espera-se que os alunos utilizem uma notação algébrica para representar a relação. Acreditamos que o aluno não terá dificuldades, mas caso apresente, o professor pode sugerir que ele utilize a linguagem algébrica atribuindo letras para representar as medidas dos ângulos. Esse uso de letras para representar as medidas passa a ser uma ação bem natural, uma vez que o GeoGebra utiliza letras do alfabeto grego para representá-los.

Feito isso, o professor pode institucionalizar o saber trabalhado. Nesse processo, ele poderá dizer que a medida de um ângulo inscrito é a metade da medida do ângulo central correspondente e representar algebricamente esta relação baseando-se nos elementos da construção. Logo após, ele pode retomar a informação do início da situação, o que pode favorecer que ele perceba que esta mesma relação vale para o ângulo inscrito e para o arco relativo a ele.

\section{A posteriori}

Muitos dos elementos que constam na análise a priori que apresentamos nos parágrafos precedentes, não foram necessários durante a implementação da sequência didática. Os diálogos iniciais referentes ao processo de construção da primeira situação nos revelam que os alunos tinham conhecimento sobre $o$ funcionamento do GeoGebra. Isso ficou evidente para nós, porque eles não tiveram dificuldades em associar aquilo que era pedido na situação com as ferramentas do software necessárias para realizar os comandos. Além disso, percebemos que os estudantes já conheciam a relação entre o ângulo inscrito e o arco associado a ele, como podemos observar no diálogo que segue:

Aluno $C: \quad$ :...A...D.

Transcrição das falas do trio

Aluna D: Metade, tá vendo? "Existe alguma relação entre as medidas desses ângulos?" Que a medida do CÊD é a metade do Ângulo CÂD.

\section{Transcrição das falas da dupla}


Aluno A: Eu acho que é o dobro! É o dobro! Um é o dobro do outro. É aquela relação que ... Eu só não lembro...

Aluno B: Que a gente viu na outra disciplina.

Estes diálogos nos revelam que os alunos, de fato, já conheciam a relação, pois assim que a construção foi finalizada, a Aluna D afirmou que a medida do ângulo inscrito é igual a metade da medida do ângulo central correspondente ao arco. Também ficou evidente, pela fala do Aluno B, que este conhecimento é resultante do estudo dos alunos em outra disciplina. Neste caso, a situação 1 perde seu caráter didático, pois não houve promoção do aprendizado, mas sim uma avaliação dos conhecimentos dos alunos.

Notamos, com isso, que os alunos saíram da situação de ação, diretamente, para a situação validação, na qual eles buscaram mais elementos para confirmar se a construção que eles estavam manipulando era uma representação do conhecimento que eles já tinham. Assim, o primeiro método utilizado pela dupla para validar sua conjectura foi a multiplicação. Eles apresentaram dificuldade apenas para lembrar o nome (ângulos inscritos) que é atribuído a ângulos que gozam dessa propriedade. Em seguida, ambos os grupos utilizaram a ferramenta Mover do GeoGebra como meio de validação da propriedade dos ângulos inscritos, ao testarem que independe da posição do vértice e do tamanho da circunferência a propriedade se mantém, como podemos ver nas transcrições que seguem:

Aluno: $\quad$ Mas aí se eu mexer cá, ó.

Transcrição do trio

Aluna A: Vocês estão vendo?... O valor não muda.

Aluna A: Independente do tamanho também?

Aluna B: Hum hum.

\section{Transcrição da dupla}

Aluno B: Você move e continua dando o dobro.

Aluno A: Se é a propriedade! Vale sempre!

\subsubsection{Situação 2: Ângulo Inscrito numa Semicircunferência:}

Esta situação destina-se a dar condições ao aluno de perceber que um ângulo inscrito numa semicircunferência terá sempre a medida de $90^{\circ}$. Esta situação é, na verdade, um caso particular de ângulos inscritos, quando ele está relacionado com um arco de $180^{\circ}$. No entanto, a situação tem uma consequência imediata que é o fato de que todo triângulo inscrito numa semicircunferência, de tal forma que um de seus lados coincida com o diâmetro, ele é retângulo. Assim, temos, a seguir, a análise, item a item, desta situação didática.

1. Construa uma circunferência de centro A e trace um diâmetro $\overline{C D}$.

Nesta construção, o aluno pode traçar uma corda que não guarda a principal propriedade para ser considerada um diâmetro, passar pelo ponto central da 
circunferência, nesse caso, ocorrerá problemas durante a investigação da construção que impedirá o aluno de perceber a relação desejada. Desse modo, caso os alunos não observem esta propriedade fundamental do diâmetro, o professor pode questioná-lo sobre a diferença entre diâmetro e uma corda qualquer, e assim chegar a que o diâmetro de uma circunferência é uma corda que, obrigatoriamente, passa pelo centro. Em seguida, na sequência, é solicitado que os estudantes:

2. Crie um ponto $E$ (distinto de $C$ e D) na circunferência e construa $o$ triângulo $\triangle C D E$. Responda:

$\mathrm{Na}$ execução deste segundo item, o aluno poderá usar o ponto B que surgirá na construção da circunferência para traçar o seu diâmetro. Ou pode ainda acontecer dele, o aluno, ocultar o ponto $\mathrm{B}$ e criar os pontos $\mathrm{C}, \mathrm{D}$ e $\mathrm{E}$ sobre a circunferência. $\mathrm{O}$ professor mediará esta situação informando-lhes que os pontos $\mathrm{C}$ e D têm que ser os extremos do diâmetro. Cumprida esta etapa, obtêm-se uma construção semelhante à Figura 2.

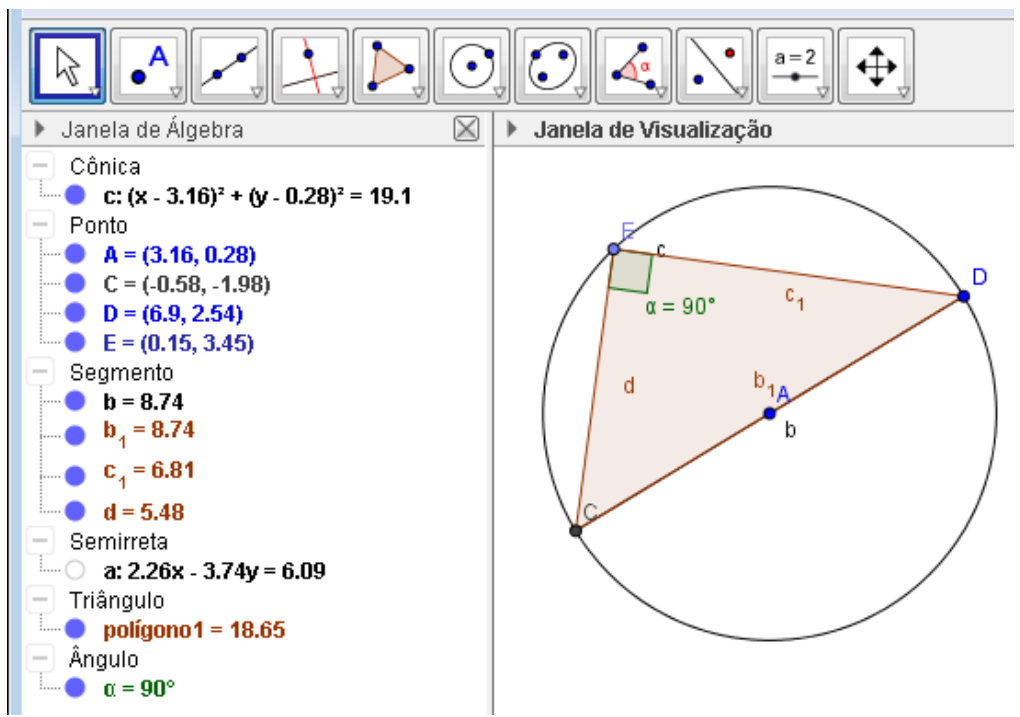

FIGURA 2: Construção, referente à Situação 2, realizada pelo trio participante da pesquisa FONTE: Dados coletados na fase de experimentação da sequência didática.

Uma vez realizada a construção, análoga a da Figura 2, na sequência didática é solicitado aos estudantes que:

a) Classifique o ângulo $C \hat{E} D$.

Para realizar esta classificação, ele, provavelmente, utilizará a ferramenta Ângulo para medi-lo, percebendo assim que se trata de um ângulo reto. Depois de responder o item a), a sequência didática é direcionada para análise do triângulo inscrito na semicircunferência, como podemos ver no item que segue.

b) Classifique o triângulo CDE quanto aos ângulos.

O que se deseja com este item é que o aluno classifique o triângulo em relação à medida dos seus ângulos internos, porém eles podem, também, classificálo como escaleno, ou seja, pela medida dos seus lados. Caso isso ocorra, o professor poderá questioná-lo se existe outra forma de classificar os triângulos. Este questionamento, provavelmente, o fará lembrar da classificação quanto aos ângulos. Contudo, acreditamos que o item a) o levará a realizar a classificação quanto aos 
ângulos internos. Após a classificação do triângulo $\mathrm{CDE}$, os itens da sequência didática são postos para que os estudantes:

c) Mova os pontos C e E. O que você observou?

Este item c) tem como objetivo influenciar o aluno a utilizar o dinamismo do GeoGebra durante a situação de ação. Com base nesse uso, promover por meio da observação de características invariantes (medida do ângulo CÊD $=90^{\circ}$ ) a formulação da propriedade e validar esta conjectura sobre triângulos inscritos numa semicircunferência.

d) O que se pode afirmar a respeito de um triângulo inscrito em uma semicircunferência?

e) Justifique matematicamente.

Com estes dois últimos itens, pretende-se que os alunos enunciem sua observação, em um formato semelhante a um teorema e exiba uma prova, uma explicação fundamentada em argumentos matemáticos que convença os seus pares, não necessariamente uma demonstração. Essa explicação pode vir com o rigor necessário para ser considerada uma demonstração ou não. Porém, na fase da situação didática de institucionalização, o professor pode realizar esta demonstração baseando-se no fato de que o ângulo CÊD é um ângulo inscrito correspondente a um arco que mede $180^{\circ}$, logo, este ângulo sempre medirá a metade desse arco, $90^{\circ}$.

\section{A Posteriori}

Durante a implementação da Situação 2 da sequência didática, ambos os grupos se preocuparam, de imediato, em construir o diâmetro passando pelo centro. Houve uma pequena discussão na busca do consenso de como construir o diâmetro. O trio optou por traçar uma semirreta de um ponto sobre a circunferência, passando pelo centro e marcar a intersecção, já a dupla traçou uma reta e procedeu de maneira análoga.

O Aluno C do trio, assim que mediu o ângulo CÊD, esboçou a compreensão da relação entre o conteúdo trabalhado na situação anterior e o valor do ângulo obtido, como podemos ver no diálogo:

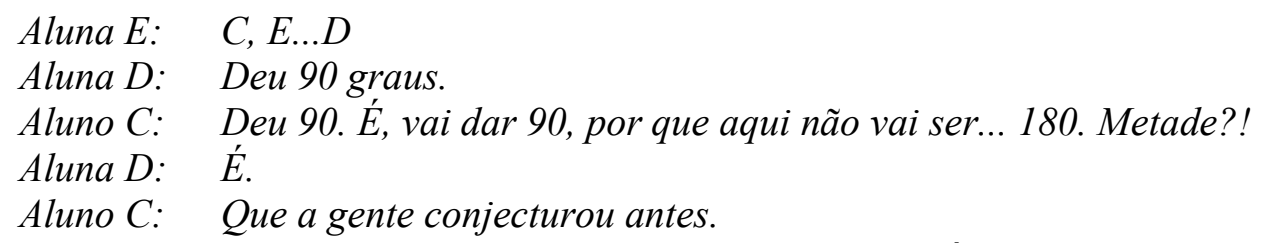

Aparentemente, o Aluno $C$ percebeu que o ângulo CÊD é um ângulo inscrito relativo a um arco de $180^{\circ}$ e, por isso, mede $90^{\circ}$. Enquanto isso, a dupla associou a medida do ângulo CÊD ao arco capaz, muito provavelmente porque eles moveram o ponto $\mathrm{E}$ e observaram que a medida do ângulo não se alterava, independentemente da posição dele na semicircunferência, as falas que seguem ratificam essa afirmação.

Aluno B: Classifique o ângulo $C \hat{E} D$

Aluno A: $\quad C \hat{E} D$. É o ângulo reto! Se aqui é o arco capaz. É o arco capaz de $90 !$ 
Além de perceberem que o CÊD sempre seria igual a $90^{\circ}$, eles deveriam apresentar uma justificativa matemática para essa propriedade. Neste momento, os alunos da dupla só conseguiram elaborar uma justificativa matemática após a intervenção do Aluno $\mathrm{C}$ do outro grupo. No entanto, o trio não teve problemas para elaborar argumentos para explicar a constância da medida, pois, de imediato, eles associaram aos seus conhecimentos sobre ângulos inscritos ao observarem que o ângulo CÊD correspondia a um arco de medida igual a $180^{\circ}$.

A noção de arco capaz é, na verdade, uma consequência da propriedade observada, por isso que associar o ângulo inscrito numa semicircunferência, como a dupla fez, não poderia ser utilizado nem mesmo para justificar invariância da medida do ângulo.

\subsubsection{Situação 3: Ângulos Excêntricos Interiores:}

Esta situação visa favorecer que os alunos percebam que o Ângulo Excêntrico Interior é igual à metade da soma das medidas dos arcos determinados por esse ângulo e pelo ângulo oposto pelo vértice a ele. Para isso, na sequência didática elaborada, solicitamos que os alunos cumpram os seguintes passos para assim obter a construção que, ao ser explorada, revelará elementos para que eles formulem esta relação do Ângulo Excêntrico Interior.

1. Crie uma circunferência de centro A;

2. Crie um ponto $C$ no interior da circunferência e os pontos $D$ e $E$ sobre a circunferência e trace as retas $\overleftrightarrow{C D}$ e $\overleftrightarrow{C E}$;

3. Marque os pontos $F$ e $G$ de intersecção das retas com a circunferência;

4. Determine os arcos $\widehat{D E}$ e $\widehat{F G}$, e mude suas cores para destacá-los;

Dados dois pontos sobre uma circunferência, eles determinam dois arcos distintos, sendo que ambos podem medir igualmente $180^{\circ}$, ou um ser maior do que $180^{\circ}$ e o outro menor. Um problema que pode ocorrer nesse $4^{\circ}$ passo da situação é o aluno marcar o arco com medida maior do que $180^{\circ}$. Essa marcação pode ocorrer, simplesmente, pelo aluno clicar em uma ordem diferente dos pontos. Para evitar este problema, o pesquisador pode fazer um acordo com os alunos que eles devem apenas marcar os arcos com medidas menores ou iguais a um ângulo raso. Não que o contrário seja considerado um erro, uma vez que desejamos obter a média aritmética das medidas dos arcos. Esse "acordo" apenas facilitará a visualização da propriedade desejada e funcionará como variável didática, escolha dos arcos. Em seguida, na sequência, é solicitado que façam medições que serão utilizadas na conjectura da relação do Ângulo Excêntrico Interno.

5. Determine as medidas do ângulo DC $E$ e dos arcos $\widehat{D E}$ e $\widehat{F G}$.

$\mathrm{O}$ aluno poderá se equivocar na hora de medir os arcos, pois ele pode medir outro Ângulo que não seja o ângulo central relativo ao arco. Assim, o pesquisador 
deve solicitar que o aluno releia as informações presentes na situação 1, e que reflita sobre como ele mediu os arcos.

6. Existe alguma relação entre as medidas dos arcos $\widehat{D E}$ e $\widehat{F G}$ e a medida do ângulo DĈE? Investigue!

Caso o aluno não consiga perceber a relação, o pesquisador poderá intervir da seguinte forma: primeiro, pedindo para que o aluno some as medidas dos arcos pelo campo de entrada do GeoGebra; após isso, o pesquisador poderá questioná-lo perguntando "qual é o resultado?". Desse modo, pode pedir para comparar o resultado da soma anterior com a medida do ângulo, e novamente questionar o aluno perguntando "o que você conclui?". Com esses passos, supõe-se que o aluno conseguirá chegar ao resultado almejado.

Como resposta, o aluno pode dizer que o ângulo $D \hat{C} E$ é a metade da soma obtida, ou que a soma obtida é igual ao dobro da medida do ângulo $D \hat{C} E$. Então, o pesquisador pode, novamente, questioná-lo: como você escreveria a medida do ângulo a partir das medidas dos $\operatorname{arcos} \widehat{D E}$ e $\widehat{F G}$ e do ângulo $D \hat{C} E$ ?

O pesquisador ainda poderia pedir para ele movimentar os pontos E, D e C e observar se a relação se mantém. Enquanto que, na fase da institucionalização, ele diria que os ângulos que possuem as características do ângulo $D \hat{C} E$ são chamados de Ângulos Excêntricos Interiores, pois eles não estão no centro da circunferência nem na região exterior desta. Além disso, ele deve falar que a medida do ângulo excêntrico interior vale a metade da medida da soma dos arcos. Após este momento, o pesquisador prosseguirá com a institucionalização do saber, representando algebricamente esta relação no quadro.

\section{A Posteriori}

O GeoGebra permite experimentações que levam os usuários a aprenderem a utilizar suas ferramentas, mesmo sem o uso de um manual. Assim, ao optar por este software, o pesquisador não terá necessidade de ensinar aos alunos os esquemas de uso para cada uma das ferramentas, pelo contrário, a busca pela ferramenta ideal para realizar uma tarefa é um processo bem intuitivo e quase que autoexplicativo. Por assim ser, o aluno pode aprender a utilizar o programa ao mesmo tempo em que constrói o conhecimento sobre o objeto matemático. Além disso, o GeoGebra permite trabalhar, ao mesmo tempo, em dois registros de representação, o que facilita a visualização e compreensão das ações. Esses fatos puderam ser observados quando os alunos tiveram que marcar dois arcos sobre uma circunferência e não sabiam qual ferramenta usar. Depois que descobriram, a "Janela Algébrica" foi utilizada para comprovar a efetividade da ação. Vejamos o diálogo que segue:

Aluno C: $\quad$ É. Determinar esses Arcos. Vai aqui. Não, nessa setinha aqui. Só encosta. Não vê lá vê no ângulo. Como é que determina arco aqui 
pelo GeoGebra?.... Está aqui. Determine o arco CE. É para gente identificar ou fazer pelo GeoGebra? Ah é! É por aqui mesmo e circunferência né? Onde foi que tu colocou agora?

Aluna D: $\quad$ Semicírculo ...

Aluno C: $\quad$ Setor circular, Circular dado três pontos ...Arco circular dado 3 pontos [lendo os nomes das ferramentas]

Aluna D: $\quad$ Eu acho que é semicírculo definido por dois, já que é um arco.

Pesquisador: Experimente.

Aluna E: Não! Então não é.

Pesquisador: Qual foi outro que vocês estavam pensando?

Aluna E: $\quad$ Arco circular dado centro e dois pontos.

Aluna D: $\quad$ Dado o centro aqui...

$$
[\ldots]
$$

Aluno C: $\quad$...e dois pontos. Apareceu alguma coisa?

Aluna E: $\quad$ Não vi não.

Aluno C: $\quad$ Apareceu, do lado de cá não?

Aluna E: Aíó!

Aluno C: $\quad$ Não, é porque ele escreveu por cima. O outro é sobre FG.

Uma vez encontrada a ferramenta necessária para a marcação dos arcos, os estudantes finalizaram a construção, apresentada na Figura 3, e se voltaram para identificar a relação.

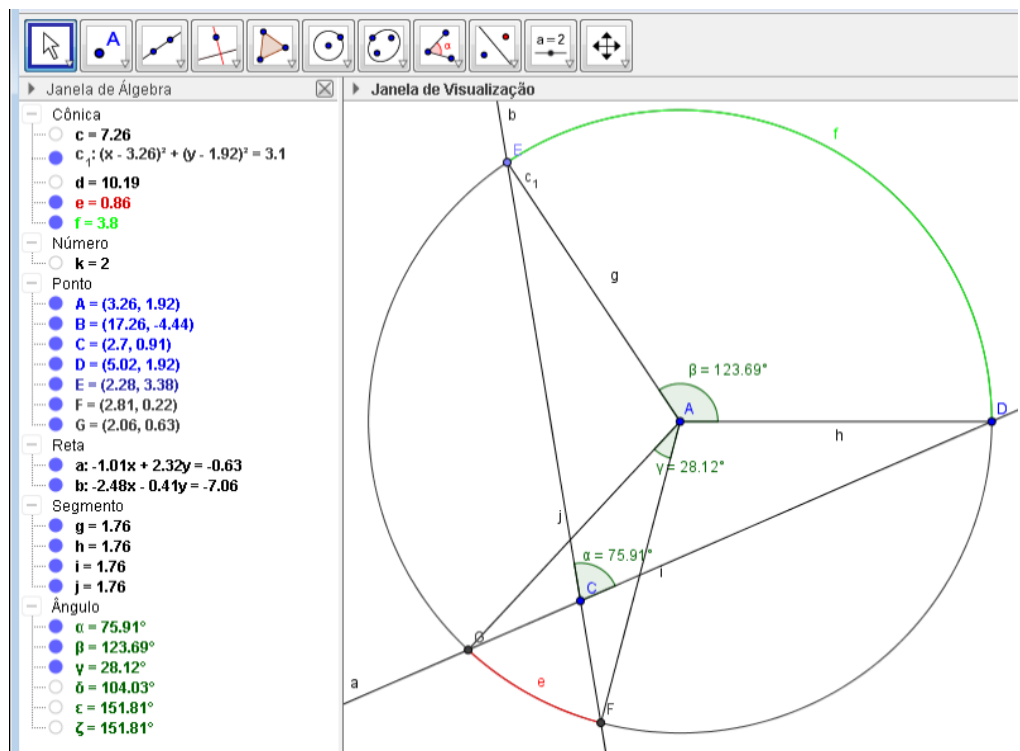

FIGURA 3: Construção realizada pelo trio referente à Situação 3

FONTE: Dados coletados na fase de experimentação da sequência didática.

O trio não conseguiu perceber a relação desejada, então o pesquisador teve que intervir e fazer uma nova devolução. Contudo, podemos notar, no diálogo que segue, que ele acabou dando parte da resposta para os estudantes.

Aluno: $\quad$ Traçou. Aqui a gente não conseguiu ver a relação não. Circunferência, ok. Crie um ponto C no interior da circunferência. 
[...] A gente não conseguiu chegar no final. Existe alguma relação entre as medidas desses arcos DE...

Pesquisador: Façam o seguinte... E se vocês pegassem a medida desses dois arcos e somasse? Some ai para a gente ver.

$[\ldots]$

Pesquisador: Aqui está dando quanto? 77, não é?

Alunos: $\quad$ 77. 121 e 69.

Pesquisador: Faz o seguinte, pega essa medida [ângulo $\varepsilon$ ] e divide por 2. Não!

Divide por esse primeiro número [ângulo $\alpha$ ] aí.

Aluna B: $\quad$ Pegar esse daqui [E] e dividir por qual?

Pesquisador: Esse $\varepsilon$ e divide pelo primeiro ângulo lá, que é o ...

Aluna B: $\quad \alpha$. Esse daqui... dividido...dividir, dividir, dividir...

Pesquisador: Dividir é [usa] barra

[...]

Pesquisador: ... Se você colocar [o cursor do mouse sobre k] sobre, $k$ é igual a

2. E aí? Observe, você pegou o que?

Aluno: $\quad$ O ângulo e dividiu.

Pesquisador: Pelo que?

Aluna B: $\quad$ A gente pegou esse ângulo e dividiu... a soma dos arcos...

Pesquisador: A soma dos arcos, $e$ ?

Aluna B: Dividiu pelo ângulo.

Pesquisador: Edeu?

Alunos: Dois.

Pesquisador: Vocês percebem alguma relação?

Aluna B: $\quad$ Esse arco aqui, é a metade da soma.

Aluna A: $\quad$ Esse aqui é a metade desse daqui, não?

$\mathrm{O}$ pesquisador poderia ter solicitado que os estudantes fizessem coincidir o ponto $\mathrm{E}$ com o ponto $\mathrm{G}$ e perguntar para qual valor o ângulo $D \hat{C} E$ se aproximava quando os arcos juntos cobriam toda a circunferência. Desse modo, os estudantes poderiam notar que este ângulo tendia para $180^{\circ}$ quando a soma dos arcos tende para $360^{\circ}$, ou seja, $D \hat{C} E$ tende para metade da soma dos arcos.

Os alunos, quando foram escrever a resposta do item 6 desta situação, ficaram na dúvida se tinham que escrever a relação ou se bastava responder com um "sim" ou um "não". Essa dúvida é decorrente, em nosso entendimento, da má redação do item. Mesmo com esse problema, o pesquisador, ao convidar os estudantes para participarem da situação de institucionalização, pôde incentivá-los a explicitarem qual relação eles perceberam. Além disso, o pesquisador apresentou uma justificativa matemática para a propriedade. Desse modo, ele realiza uma renegociação do contrato didático estabelecido, pois, a partir desse momento, os estudantes passam a saber que sempre lhes será solicitado explicitar (verbalmente ou por escrito) a propriedade observada e elaborar argumentos matemáticos para justificar sua existência. Assim, vemos que o momento da institucionalização, pode 
ser utilizado para minimizar os efeitos de possíveis falhas na situação proposta, as quais, porventura, não foram identificadas na análise $a$ priori.

\subsubsection{Situação 4: Ângulos Excêntricos Externos:}

O objetivo desta situação é que o aluno perceba que, dado um ponto D externo, a circunferência e dois pontos (B e C) sobre ela, é possível determinar um ângulo de vértice em $\mathrm{D}$, o qual será chamado de Ângulo Excêntrico Externo. Além disso, busca-se que o aluno conjecture que a medida do ângulo $C \widehat{D} B$ seja igual à metade da diferença entre as medidas dos arcos da circunferência que estão entre os lados de $C \widehat{D} B$. Para isso, na sequência didática, foi solicitado que os estudantes realizassem a construção dos itens 1,2 e 3 .

1. Crie uma circunferência de centro A passando por B;

2. Crie os pontos $C$ sobre a circunferência e $D$ externo a circunferência e trace as semirretas $\overrightarrow{D B}$ e $\overrightarrow{D C}$;

3. Marque os pontos E e F que são as intersecções das semirretas $\overrightarrow{D B}$ e $\overrightarrow{D C}$, respectivamente, com a circunferência;

Para marcar esses dois pontos de intersecção, o aluno poderá utilizar a ferramenta "Ponto" e clicar no encontro da semirreta $\overrightarrow{D B}$ com a circunferência, criando assim o ponto $\mathrm{E}$, que talvez tenha que ser renomeado e, procedendo da mesma forma, só que clicando no encontro de $\overrightarrow{D C}$ com a circunferência, marcará o ponto $\mathrm{F}$.

Outra forma de realizar este terceiro passo, seria por meio da ferramenta "Intersecção de Dois Objetos". No entanto, a depender de como ele utilize esta ferramenta, ocorre também a criação de objetos desnecessários que podem "poluir a construção". Isso ocorrerá se o aluno clicar na semirreta e na circunferência em vez de clicar diretamente nos pontos de intersecção dessas curvas. Caso isso ocorra, basta que o pesquisador solicite que ele apague ou oculte os pontos que aparecerão sobrepostos aos pontos B e C. Esse cuidado é necessário para facilitar a visualização da construção e, posteriormente, a conjectura. A situação 4 continua com a tarefa que segue.

4. Marque os arcos que estão entre as duas semirretas, e mude sua cor para destacá-los;

Estes arcos que estão entre as duas semirretas (lados do ângulo $C \widehat{D} B$ ) podem ser $\mathrm{BC}$ e EF ou BF e CE a depender da construção realizada pelo aluno, assim, o pesquisador precisará considerar isso durante a situação didática de institucionalização, a fim de que o aluno não pense que suas conclusões estão erradas, quando, na verdade, ele apenas fez uma construção diferente. Inclusive, é relevante que este caso ocorra para que o aluno não fique preso a uma fórmula

Revista do Instituto GeoGebra de São Paulo, v. 9, n. 3, p. 46-73, 2020 - ISSN 2237-9657 
algébrica fixa, o que pode dificultar a resolução de situações matemáticas que requeiram este saber específico.

5. Determine as medidas do ângulo $C \widehat{D} B$ e dos arcos marcados no passo anterior;

Mais uma vez, as informações contidas na situação 1 serão utilizadas pelos alunos, pois as medidas dos arcos estão associadas aos respectivos ângulos centrais de cada arco. Uma vez que o aluno realize estas medições, ele terá os elementos necessários para uma situação adidática de formulação.

6. Existe alguma relação entre as medidas dos arcos e a medida do ângulo $C \widehat{D} B$ ? Investigue!

A pergunta levará o aluno a vivenciar a situação adidática de formulação, em que se espera que ele elabore o modelo explícito, a relação entre o Ângulo Excêntrico Externo e os arcos da circunferência que estão entre os lados deste ângulo.

Caso os alunos não consigam perceber esta relação, o professor pode proceder com os seguintes questionamentos, que fazem parte de um novo processo de devolução: subtraia as duas medidas dos $\operatorname{arcos} \widehat{B F}$ e $\widehat{C E}$ pelo campo de "Entrada" do GeoGebra; qual o resultado?; meça o ângulo $B \widehat{D} C$; compare o resultado da subtração anterior com a medida do ângulo $B \widehat{D} C$; o que se pode concluir?; divida a subtração anterior por dois e compare o resultado com o ângulo $B \widehat{D} C$; como você pode escrever a medida do ângulo $B \widehat{D} C$ a partir das medidas dos $\operatorname{arcos} \widehat{B F}$ e $\widehat{C E}$ ? Com esses passos, espera-se que o aluno consiga chegar à relação, a qual diz que $o$ Ângulo Excêntrico Exterior é igual à metade da diferença dos dois arcos determinados pelos lados desse ângulo e interiores ao ângulo.

Após esse momento, o pesquisador pode institucionalizar esse saber. Nesse momento, o pesquisador poderá usar as próprias construções do GeoGebra para proceder com a institucionalização, a qual também pode ser feita algebricamente.

\section{A Posteriori}

Destacamos dos áudios oriundos da aplicação da sequência didática os diálogos que seguem, os quais nos revelam que a ideia de somar medidas foi utilizada também para resolver esta situação. Podemos perceber, também, que outras ações utilizadas na identificação das propriedades em situações anteriores são retomadas para tentar descobrir a nova propriedade. Por exemplo, vemos no diálogo a seguir a tentativa de multiplicar ou dividir por dois.

Aluno C: C...D...B. Aqui 17.

Aluna D: Ham. E os arcos? Soma esses dois para ver quanto é que vai dar.

Aluno $C:$ A soma de...

Aluna D: Tá... e não consegue enxergar nada né? Não dá metade. Dáo triplo? 
Aluno C: $\quad$ Esse com esse, a soma deles deu quando aqui... Dá 57. Não dá o triplo.

Quando estas ações falham, eles tentam outras semelhantes, como é o caso da verificação se o valor obtido é o triplo do outro. Vemos com isso que eles entram num constante vai-e-vem entre as situações de formulação e validação, pois elaboram uma conjectura, tentam validá-la, mas quando ela falha, eles elaboram outra e entram em novo processo de validação. A literatura indica que a situação de validação serve para comprovar, como também para rejeitar ideias. Dado que a relação procurada não foi encontrada de imediato, eles mantiveram a estratégia utilizada anteriormente, de somar as medidas dos ângulos, foi assim que uma das alunas teve o primeiro vislumbre de qual seria a relação, vejamos:

\footnotetext{
Aluna D: $\quad 34 ! 34$, quando soma esse aqui fica faltando quase a mesma coisa do de cá. Tu acha o que?

Aluno C: $\quad$ Do que? Eu estava pensando cá alto. É... eu já vi. Eu acho que

Pesquisador: E como é? eu enxerguei aqui.

Aluno C: $\quad$ Somando 16 com 18.

Aluna D: $\quad$ Vai dar 34.

Aluno C: $\quad 34$. Menos 50?

$\mathrm{O}$ que primeiro eles perceberam foi que a soma das medidas do ângulo excêntrico externo com o arco menor, menos a medida do arco maior, resulta na mesma medida do ângulo excêntrico externo. Para tentar confirmar esta conjectura, eles moveram o ponto $\mathrm{D}$, vértice do ângulo excêntrico, que pode ser visto na Figura 4, alterando assim as medidas dos arcos e do próprio ângulo. Com estes novos valores, eles aplicaram o algoritmo e ficaram, cada vez mais, convencidos de que a sua conjectura era verdadeira, refinando a conjectura na fase de formulação. Eles ainda somavam os valores mentalmente, mas como havia diferenças, decorrentes dos valores das casas decimais entre o valor obtido e a medida do Ângulo, o Aluno sugeriu que eles utilizassem o GeoGebra para realizar as contas.
} 


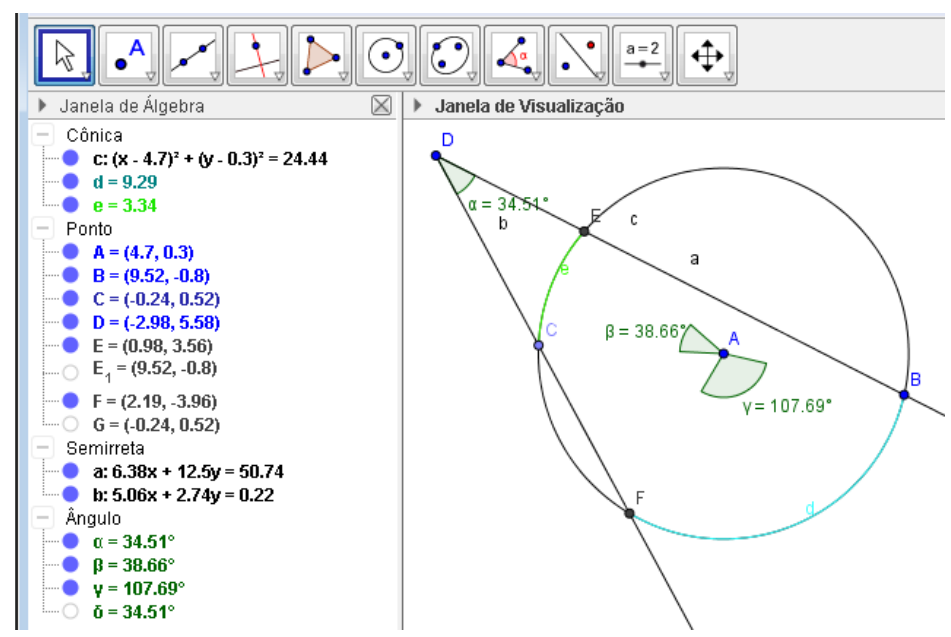

FIGURA 4: Construção relativa à situação 4, realizada pelo trio participante da pesquisa FONTE: Dados coletados na fase de experimentação da sequência didática.

Contudo, o pesquisador sugeriu que eles escrevessem, algebricamente, o que eles tinham pensado. Assim o fizeram e obtiveram a seguinte equação: $\alpha+\beta-\gamma=$ $\alpha$, onde $\alpha, \beta$ e $\gamma$ são as medidas dos ângulos que podem ser vistos na Figura 4. Então, ao escreverem e atribuir os valores às variáveis, perceberam que, do jeito que eles falaram, o resultado sempre seria negativo, porém, eles não tinham se atentado a isso, uma vez que eles consideravam o resultado em módulo automaticamente. Acreditamos que, pelo fato deles estarem trabalhando com medidas de ângulo e saberem que estas medidas são sempre valores não-negativos, eles faziam a correção do resultado obtido a partir do modelo elaborado, sem corrigir o modelo em si, que era falho.

Certamente, este resultado negativo também seria percebido caso eles tivessem efetuado as operações pelo GeoGebra, pois ele retornaria a um valor negativo, levando os estudantes a reavaliarem seu modelo. Mesmo assim, podemos extrair desse fato a importância de uma representação por escrito de um modelo, para que ele possa, realmente, ser validado.

\subsection{Validação}

$\mathrm{Na}$ análise a priori previmos que ocorreriam as três fases da situação adidática, porém, na Situação 1, os estudantes pularam a situação de formulação e foram direto para a validação. Esse fato, como vimos na análise a posteriori, aconteceu porque eles já eram conhecedores da relação entre a medida do ângulo inscrito e a do arco determinado por ele. Por meio da comparação das duas análises, percebemos que uma situação construída para promover o aprendizado pode se tornar em um instrumento para a sua avaliação, desde que ela seja diferente do utilizado para a construção do conhecimento pelo aluno. Isso ocorre porque, segundo a Teoria das 
Situações Didáticas, podemos afirmar que um aluno aprendeu se ele é capaz de mobilizar o saber em uma situação distinta da que deu origem ao conhecimento.

O mesmo ocorreu para o trio de alunos ao tentarem resolver a situação 2. No entanto, para a dupla, esta situação contribuiu para a aprendizagem dos estudantes. Essa aprendizagem ocorreu, porque, segundo a análise $a$ priori, esta situação era um caso particular da primeira, porém, era um caso que não estava associado ao conhecimento sobre ângulos inscritos dos alunos que compunham a dupla. Desse modo, por meio da situação 2 , eles agregaram um novo elemento às suas imagens mentais ${ }^{8}$ do conceito.

Essa mesma situação serviu para evidenciar que os alunos já tiveram contato com o estudo do arco capaz, mas que este era um conhecimento que estava desprovido de relações com os ângulos inscritos. A associação do ângulo inscrito na semicircunferência com o arco capaz não foi prevista na análise $a$ priori, fato que dificultou a intervenção dos pesquisadores, quando a dupla tentou utilizar desse saber para justificar a invariância de $90^{\circ}$ da medida do ângulo. Assim, podemos perceber que o arco capaz, enquanto lugar geométrico dos pontos que enxergam o diâmetro de uma circunferência sob um ângulo de $90^{\circ}$, não foi percebido na análise a priori nem os alunos tinham este conhecimento. Desse modo, o fato de uma semicircunferência ser o arco capaz de um ângulo de $90^{\circ}$ graus não pode ser usado para justificar, matematicamente, a invariância da medida do ângulo CÊD, em verdade, isso é uma consequência desse fato.

A mediação proposta na análise a priori para a situação 3 não foi adequada, pois tirou dos estudantes a responsabilidade de resolver parte do problema. Mesmo que eles ainda tenham encontrado dificuldades em escrever a relação, a ideia de adicionar é, sem dúvida, um ponto chave e foi "entregue" sem nenhum esforço cognitivo para os estudantes. Esse é um exemplo de uma lacuna na análise a priori de uma sequência didática que gera problemas significativos na sua fase de implementação. Além disso, esse tipo de intervenção pode gerar alteração no contrato didático, uma vez que o aluno passa a saber que, se enfrentar alguma dificuldade na identificação da relação desejada, o professor lhe dará a chave para encontrá-la. Assim, o aluno desenvolve uma dependência das "dicas do professor" e reduz a atenção dada às reações do meio. Com isso, notamos que a exploração da construção proposta na análise a posteriori poderia ajudar os alunos a descobrirem a relação de uma forma mais autônoma.

Mesmo que a intervenção realizada na situação 3 não tenha sido a mais adequada, ela serviu para reforçar uma cláusula do contrato didático, a de que toda

\footnotetext{
8 Pais (1996, p. 70) afirma que imagem mental não é algo simples de ser definido, mas pode ser compreendida como a capacidade "de enunciar, de uma forma descritiva, propriedades de um objeto ou de um desenho na ausência desses elementos".
} 
situação proposta pelo professor tem a intenção de ensinar algo. Isso ocorreu após os alunos cogitarem a possibilidade de não existir nenhuma relação entre o Ângulo Excêntrico Interno e a média das medidas dos arcos, e depois descobrirem que estavam errados. Esse fato, levou-os a persistirem na identificação da relação entre o Ângulo Excêntrico Externo e as medidas dos arcos da circunferência internos a ele. Neste momento, a estratégia dada pelo pesquisador na situação anterior, somar as medidas, continuou sendo utilizada na situação 4 e foi graças a ela que os estudantes elaboraram seu primeiro modelo para resolução da situação.

Quando os pesquisadores perceberam que sua intervenção na situação 3 facilitou mais do que o necessário no trabalho dos estudantes, eles abandonaram a estratégia prevista na análise a priori da situação 4, a qual consistia em indicar que os alunos subtraíssem os valores dos arcos. Essa mudança de estratégia evidencia o caráter de melhoria constante da sequência didática que faz parte dos pressupostos da Engenharia Didática.

Como o uso da soma colocou os estudantes no caminho da descoberta da solução da situação, os pesquisadores optaram por sugerir que eles utilizassem a representação algébrica para uma melhor compreensão do modelo procurado. No entanto, essa mudança de estratégia quase que conduziu o trio ao fracasso, pois, ao traduzirem o modelo da linguagem materna para a algébrica, eles desconsideraram o fato de que a subtração não é uma operação comutativa no corpo dos reais, o que resultou na anulação de um dos termos, a medida do ângulo $B \widehat{D} E$. Essa anulação os fez imaginar que estavam no caminho errado para solucionar a situação.

Esse quase fracasso também pode ser apontado com uma possível lacuna na análise a priori, pois, em nenhum momento, foi cogitado a possibilidade de os estudantes utilizarem a estratégia da situação 3 para chegar na solução da situação 4 . Quando se constrói uma sequência didática com objetos do saber tão intimamente relacionados, deve-se sempre cogitar formas de o aluno reaproveitar suas estratégias de uma situação para outra. Não fosse a confiança que os alunos, aparentemente, depositavam nos resultados obtidos pelo GeoGebra, eles certamente teriam recomeçado todo o processo do zero, desde a construção. No entanto, como eles já haviam testado sua primeira conjectura utilizando esses resultados no GeoGebra, eles persistiram e identificaram a falha na sua conjectura. Assim, a situação 4 nos mostrou que os alunos podem validar um modelo que se aproxima do desejado, mas que não o é de fato. Além disso, a confiança transmitida por um software construído sob pressupostos matemáticos estimula os alunos na exploração e melhoria do modelo obtido.

\section{Algumas considerações}


Nesta pesquisa foi possível identificar três tipos de uso do GeoGebra. O primeiro foi o de suporte para construção, ou seja, o programa foi utilizado como um ambiente com papel e lápis. A segunda foi a de ferramenta para conjectura e validação, como o observado nas situações 1 e 2 , nas quais os objetos geométricos abordados já faziam parte dos conhecimentos dos alunos, mesmo assim, eles utilizaram a dinamicidade do software para validar e confirmar que se tratava de uma representação. E o terceiro uso foi como fonte de dados confiáveis, pois, em nenhum momento, os alunos duvidaram se os resultados mostrados no programa estavam corretos, antes disso, eles duvidavam de si mesmos, ou seja, se eles executaram a construção de forma coerente à apresentada no enunciado das situações.

Dessa forma, acreditamos que o GeoGebra foi um elemento-chave na preparação do meio em que ocorreram as interações entre os entes - professor, aluno e saber - propiciando, como pudemos observar, o aprendizado dos estudantes. Durante a elaboração da sequência, notamos que a forma que o GeoGebra funciona deixava evidente quais as possíveis variáveis didáticas que poderíamos lançar mão para que alcançássemos os objetivos de cada situação. Assim, o GeoGebra contribuiu como um ambiente dotado dos elementos necessários e confiáveis para o desenvolvimento de cada situação. Ele favoreceu a exploração das construções, a conjectura de relações e validação de explicações para o comportamento das construções.

Além disso, deve ser considerado o fato de a sequência ter sido pensada e mediada com base na TSD, o que proporcionou que conseguíssemos que os alunos passassem pelas situações de ação, formulação e validação, com o auxílio das construções no GeoGebra, e que eles refletissem enquanto faziam as construções no software. A TSD contribuiu também ao nos dar suporte no processo de mediação da resolução das situações propostas, principalmente pela visão decorrente dos conceitos de devolução, variáveis didáticas e de contrato didático. Esses conceitos nos conduziram a estar em permanente atenção para não tirar do aluno a responsabilidade sobre sua própria aprendizagem.

Atribuímos parte dos benefícios decorrentes do uso do GeoGebra ao fato de que os participantes já haviam cursado uma disciplina na qual aprenderam a utilizálo, assim, os problemas que derivariam da falta de conhecimento do funcionamento do software foram consideravelmente reduzidos. E, como vimos na situação 4, mesmo desconhecendo qual ferramenta usar para marcar os arcos de uma circunferência, e como usá-la, os alunos conseguiram realizar a atividade de forma autônoma. Isso só foi possível porque este programa de geometria dinâmica possui uma interface bastante intuitiva. 
No entanto, reconhecemos como limitações da pesquisa o fato de que a sequência foi implementada com estudantes de licenciatura em matemática, os quais tinham certa afinidade com a forma de argumentar em matemática. Além disso, eles sabiam utilizar o GeoGebra, fato que reduziu o tempo necessário para o desenvolvimento da pesquisa e, talvez, tenha evitado que surgissem outras dificuldades a serem contornadas. Também consideramos que a quantidade de estudantes pode ter mascarado problemas que só surgirão em turmas maiores, por exemplo, como o pesquisador auxiliaria os alunos em suas dúvidas sem lhes dar a resposta.

Embora as construções feitas no GeoGebra não tenham a "força" de uma demonstração matemática, vimos que o processo de validação, por meio de seus recursos, era aceito de forma equitativa pelos estudantes. Isso, certamente, é um aspecto a ser superado em uma futura implementação com alunos da Educação Básica. Vemos, com isso, o caráter cíclico de constante melhoria de uma sequência didática elaborada sob os pressupostos da Engenharia Didática. A cada novo contexto, surgem novos elementos a serem considerados para que o aprendizado ocorra.

\section{Referências}

ALMOUloud, S. A. Fundamentos da Didática da Matemática. Curitiba: Editora UFPR, 2007, p. 218.

ARTIGUE, M. "Ingénierie Didactique". Recherches en Didactique des Mathématiques. Grenoble: La Pensée Sauvage-Éditions, v. 9.3, p. 281-308, 1988.

BAIRRAL, M. A.; BARREIRA, J. C. F. Algumas Particularidades de Ambientes de Geometria Dinâmica na Educação Geométrica. Revista do Instituto GeoGebra de São Paulo, ISSN 2237-9657, v. 6, n. 2, p. 46-64, 2017.

BALACHEFF, N.. Preuve et démonstration en matématiques au collège. Recherches em Didactique des Matémathiques, Grenoble, v. 3, n. 3, p. 261-304, 1982.

BRASIL. Secretaria de Educação Fundamental. Parâmetros Curriculares Nacionais: matemática. Brasília: MEC/SEF, 1998.

BRASIL, Secretaria de Educação Básica. Base Nacional Comum Curricular: educação é a base, Brasília: MEC, 2017. Disponível em: <https://goo.gl/bDM4YP>. Acesso em: 07 ago. 2018.

BROUSSEAU, G. Iniciación al estudio de la teoría de las situaciones didácticas. $1^{\text {a }}$ ed. Tradução: Dilma Fregona. Buenos Aires: Libros Zorzal, 2007, p.128. (Formación Docente). 
CHEVAllard, Y. BOSCH, M.; GASCÓN, J. Estudar Matemáticas: O Elo Perdido entre o Ensino e a Aprendizagem. Tradução de Daisy Vaz de Moraes, Porto Alegre: Artes Medicas, 2001.

FERRAGINA, R. et. al. GeoGebra entra al aula de matemática. $1^{\text {a }}$.ed., Buenos Aires: Miño y Davila, 2012, p. 157.

HENRIQUES, A. Reflexões sobre análises institucionais e sequência didática: o caso do estudo de integrais múltiplas. (Progressão de Carreira do Magistério Superior, de Adjunto a Titular). UESC-BA, 2011. Disponível em: https://sites.google.com/site/gpemac/dissertacoes-de-mestrado. Acessado em 15 out. 2020 .

JONES, K.; TEZEKAKI, M. Research on teaching and learning of geometry. In A. Gutiérrez, G.Leder, \& P. Boero (Eds.). Second Handbook of Research on Psychology of Mathematics Education, p. 109-149, 2016.

LOPES, M. M. Sequência didática para o ensino de trigonometria usando o software GeoGebra. Bolema, Rio Claro, v. 27, n. 46, p. 631-644, Ago. 2013. Disponível em: $<\quad$ https://doi.org/10.1590/S0103-636X2013000300019 >. Acessado em: 10 ago. 2020.

MELO, S. R.; DRAGHI, D.; SALDIVIA, F. Enseñando geometría utilizando el Software Dinámico GeoGebra: análise didáctico de una propuesta de enseñanza. Revista de Informes Científicos. Vol 8, No 1, p. 221-243, Out. 2015. Disponível em $<$ https://dialnet.unirioja.es/descarga/articulo/5454195.pdf $>$ Acessado em: 10 ago. 2020 .

NOGUEIRA FARIAS, V. L.; FARIAS, L. M. S. Construção de situações de aprendizagem em geometria plana utilizando o software cabri-geomètre: 0 deslocamento no ambiente computacional cabri-geomètre. In: ENCONTRO NACIONAL DE EDUCAÇÃO MATEMÁTICA, 9., v.1, 2007, Belo Horizonte. Anais... Disponível em: < https://www.researchgate.net/publication/340741991_Construcao_de situacoes de aprendizagem_em geometria plana_utilizando_o_software cabrigeometre_o_deslocamento_no_ambiente_computacional_cabri-geometre $>$ Acesso em: 10 ago. 2018.

PAIS, L. C. Intuição, Experiência e Teoria Geométrica. Zetetiké, São Paulo, v. 4, n. 6, p. 65-74, jul/dez. 1996.

PAIS, L. C. Didática da Matemática: uma análise da influência francesa. 2.ed. Belo Horizonte: Autêntica, 2002, p. 136. 